\title{
Octreotide enhances the sensitivity of the SKOV3/DDP ovarian cancer cell line to cisplatin chemotherapy in vitro
}

\author{
YANG SHEN, MULAN REN, YUEHUA SHI, YUNXIA ZHANG and YUNLANG CAI \\ Department of Obstetrics and Gynecology, Zhongda Hospital, Southeast University, Nanjing 210009, P.R. China
}

Received April 1, 2011; Accepted August 2, 2011

DOI: $10.3892 / \mathrm{etm} .2011 .330$

\begin{abstract}
The present study aimed to investigate the effects of octreotide (OCT) on the reversal of resistance of cisplatin-resistant cancer cells and on enhancement of the cisplatin sensitivity of cancer cells. The 3-(4,5-dimethylthiazol-2-yl)-2-5-diphenyltetrazolium bromide method and flow cytometry were used to investigate the effect of cisplatin, OCT or the combination of these two compounds on the proliferation and apoptosis of SKOV3/DDP cells. Real-time, quantitative RT-PCR was used to detect the mRNA expression of SSTR2, MDR1, MRP2, GST- $\pi$ and EGFR in SKOV3/DDP cells following OCT treatment. At the concentration of $2.5-20 \mu \mathrm{g} / \mathrm{ml}$, OCT significantly reduced the $\mathrm{IC}_{50}$ value $(\mathrm{P}<0.05)$ and promoted apoptosis $(\mathrm{P}<0.05)$ in the SKOV3/DDP cells in response to cisplatin. The synergistic effect of OCT and cisplatin on SKOV3/DDP cell proliferation was observed. SSTR2 was expressed on the SKOV3/DDP cell surface. OCT increased GST- $\pi$ expression $(\mathrm{P}<0.05)$ and reduced MRP2 and EGFR expression $(\mathrm{P}<0.05)$ in a dose-dependent manner. However, it had no effect on the expression of MDR1 ( $\mathrm{P}>0.05)$. It is suggested that OCT inhibits ovarian cancer proliferation and promotes apoptosis, via the cell surface expression of SSRT2, and reverses cisplatin resistance through the inhibition of MRP2 and EGFR expression.
\end{abstract}

\section{Introduction}

Ovarian cancer is a serious and under-recognized tumor which represents a great threat to women's health. Approximately 23,000 women are diagnosed with ovarian cancer each year, and the 5-year survival rate is $30 \%$ (1). Surgery, combined with chemotherapy, is the main treatment method for ovarian cancer. Platinum-based chemotherapy enhances the overall response, clinical remission and median survival rates of ovarian cancer patients. However, it is also an obstacle to

Correspondence to: Dr Mulan Ren, Department of Obstetrics and Gynecology, Zhongda Hospital, Southeast University, Nanjing 210009, P.R. China

E-mail: renmulan@seu.edu.cn

Key words: octreotide, somatostatin, epithelial ovarian cancer, resistance reversal the clinical treatment for primary and/or acquired multidrug resistant (MDR) tumor cells. Therefore, it is important to explore new types of drugs that reverse chemotherapy resistance and enhance sensitivity to platinum-based chemotherapy drugs.

Somatostatin (SST) is a type of hormone which was first isolated from the hypothalamus of sheep. It is located in most human organs and tissues and has a variety of functions, including the inhibition of hormone secretion, regulation of neural transmission and cell proliferation. The somatostatin analogue (SSTA) shares similar physiological activities with natural SST, but has more powerful effects and a longer half-life. It has been shown that SSTA not only inhibits the proliferation of neuroendocrine tumors in vitro, but also inhibits solid tumor growth in vivo (2-4). The specific somatostatin receptor (SSTR), with five subtypes, mediates the functions of SSTA. More than two receptor subtypes are easily detected in most types of tumor tissue, particularly SSTR2. SSTR2 mediates the inhibition of cell proliferation via the activation of Ras-, Rapl- and B-Raf-dependent extracellular signal-regulated kinase 2 (Erk2) (3-5). It has been reported the SSTR is expressed in ovarian cancer cells $(6,7)$, suggesting that SSTA may be involved in ovarian cancer. Recent studies have shown that SST and SSTA enhance chemotherapeutic drug sensitivity in a variety of resistant tumor cells (8). However, the function of SST and SSTA in the enhancement of cisplatin sensitivity in resistant ovarian cancer cells remains unclear. This study investigated the function and mechanism of octreotide, one type of octapeptide SSTA, on cisplatin-resistant SKOV3/DDP ovarian cancer cell growth and resistance reversal. Our results provide a new understanding of the clinical treatment of ovarian cancer and drug resistance reversal.

\section{Materials and methods}

Effects of cisplatin, octreotide and their combination on SKOV3/DDP cell proliferation. SKOV3/DDP cells $\left(1 \times 10^{4}\right)$ in the logarithmic phase were seeded in 96-well culture plates and cultured at $37^{\circ} \mathrm{C}$ under a $5 \% \mathrm{CO}_{2}$ atmosphere for $24 \mathrm{~h}$. The cultured medium was removed after the cells adhered to the plate wall. The cells were then incubated in $200 \mu \mathrm{l}$ of medium with octreotide (OCT) $(0,1.25,2.5,5,10$ and $20 \mu \mathrm{g} / \mathrm{ml})$, cisplatin $(0,1,2,4$ and $8 \mu \mathrm{g} / \mathrm{ml})$ or a combination of both OCT and cisplatin at each concentration listed previously. The blank control group was constructed using an equal volume of culture 
Table I. Primer sequences for the real-time PCR reaction.

\begin{tabular}{|c|c|c|c|}
\hline Objective gene & Primer sequence & Primer length (bp) & Annealing temperature $\left({ }^{\circ} \mathrm{C}\right)$ \\
\hline SSTR2 & $\begin{array}{l}\text { 5' TCAACCAACACCTCAAACCAGAC 3' } \\
\text { 5' CCCAATGATGCAGACCACAAAAT 3' }\end{array}$ & 93 & $\begin{array}{l}61.4 \\
63.6\end{array}$ \\
\hline MDR1 & $\begin{array}{l}\text { 5' TTGACAGCTACAGCACGGAAGG 3' } \\
\text { 5' GTCGGGTGGGATAGTTGAATAC 3' }\end{array}$ & 90 & $\begin{array}{l}62.8 \\
57.9\end{array}$ \\
\hline EGFR & $\begin{array}{l}\text { 5' TAACGGAATAGGTATTGGTGAAT 3' } \\
\text { 5' GAGGAGGAGTATGTGTGAAGGAG 3' }\end{array}$ & 149 & $\begin{array}{l}55.8 \\
57.3\end{array}$ \\
\hline MRP2 & $\begin{array}{l}\text { 5' CCATCATCCATAGCTTCATTCC 3' } \\
\text { 5' GTGCGTTTCAAACTTGCTCACT 3' }\end{array}$ & 156 & $\begin{array}{l}58.8 \\
59.8\end{array}$ \\
\hline GST- $\pi$ & $\begin{array}{l}\text { 5' GATGCGTTCCCCCTGCTCTC 3' } \\
\text { 5' CCCAACCCTCACTGTTTCCC 3' }\end{array}$ & 128 & $\begin{array}{l}64.1 \\
61.4\end{array}$ \\
\hline$\beta$-actin & $\begin{array}{l}\text { 5' GCAGAAGGAGATCACTGCCCT 3' } \\
\text { 5' GCTGATCCACATCTGCTGGAA 3' }\end{array}$ & 136 & $\begin{array}{l}61.0 \\
60.0\end{array}$ \\
\hline
\end{tabular}

medium without the drugs. Each group consisted of three parallel wells, and each experiment was repeated three times for each group. For the OCT group, cells were cultured for predetermined times $(24,48,72$ and 96 h). Then, the cells were treated with $20 \mu \mathrm{l}$ of the 3-(4,5-dimethylthiazol-2-yl)-2-5-diphenyltetrazolium bromide (MTT) reagent $(500 \mu \mathrm{g} / \mathrm{ml})$ for $4 \mathrm{~h}$, and lysed in $150 \mu \mathrm{l}$ of dimethyl sulfoxide solvent reagent for 10 min. Absorbance (A) was measured on an enzyme-linked immunosorbent assay plate reader. The inhibition rate was calculated using the following formula: Cell proliferation inhibition rate $=$ (average of value $\mathrm{A}$ from the control group the average of value A from the experimental group)/(average of value A from the control group - average of value A from blank controller) x $100 \%$. All experiments were repeated in triplicate and more than three wells were used for each treatment. According to the results of the octreotide treatment, the same methods described above were used to detect the values of A for cisplatin and the two-drug combination groups. A time-concentration curve was constructed using the average value of three tests. The drug concentration of the $50 \%$ inhibition rate $\left(\mathrm{IC}_{50}\right)$ was calculated using the weighted linear regression method with Excel software. An $\mathrm{IC}_{50}$ curve of the effects of OCT on cisplatin was created.

Effects of cisplatin, OCT and their combination in SKOV3/DDP cell apoptosis. According to the MTT results, the experiments were divided according to four treatment groups, including the control, cisplatin $(2.0 \mu \mathrm{g} / \mathrm{ml})$, OCT $(10.0 \mu \mathrm{g} / \mathrm{ml})$ and the two-drug combination groups. Following treatment for $36 \mathrm{~h}$, an apoptosis test was carried out according to the instructions provided in the Annexin V-FITC/PI staining kit, and the results were read using flow cytometry.

Effectofcisplatin,OCTandthetwo-drugcombinationonSSTR2, EGFR, MDR1 and MRP $2 \mathrm{mRNA}$ expression in SKOV3/DDP cells. Total RNA was extracted from the cells according to instructions provided in the RNeasy Mini kit (KGA1203; Kaiji Company). The extracted RNA was dissolved in DEPC water. The absorption values at 260 and $280 \mathrm{~nm}$ were detected using a UV spectrophotometer. The RNA concentration was calculated using the following formula: RNA concentration = OD260 x dilution fold $\times 0.04 \mu \mathrm{g} / \mu \mathrm{l}$. The quality was considered satisfactory when the OD260/280 value was in the range of 1.8 to 2.1. The OD260/280 value was also investigated using ultraviolet spectroscopy. A $2-\mu 1$ sample of cDNA was added to the reaction mixture, and the cDNA was synthesized according to the instructions provided in the RT-PCR kit (KGA1303; Kaiji Company). Primers were designed and synthesized by the Kaiji Company, as shown in Table I. Realtime PCR was performed in a Light Cycler (Roche Applied Science) under the following conditions: denaturation at $95^{\circ} \mathrm{C}$ for $5 \mathrm{~min}$ with an additional $15 \mathrm{sec}$ at $94^{\circ} \mathrm{C}$, and a $30-\mathrm{sec}$ annealing at $60^{\circ} \mathrm{C}$. Comparing the threshold method and the mathematical method, the amount of target gene was equal to $2^{-\Delta \Delta c t}$. $\mathrm{Ct}$ is the number of cycles of fluorescence required for it to reach the threshold:

$\Delta \Delta \mathrm{Ct}=\left(\mathrm{Ct}_{\text {objective gene }}-\mathrm{Ct}_{\text {reference gene }}\right)_{\text {experimental group }}-\left(\mathrm{Ct}_{\text {objective gene }}\right.$
$\left.-\mathrm{Ct}_{\text {reference gene }}\right)_{\text {control group }}$

Using this method, we were able to directly quantify the target gene relative to the reference gene ( $\beta$-actin) and compare the common logarithm of the relative value of the target gene and control gene.

Statistical analysis. Statistical analysis was performed using SPSS 16.0 software. Data are expressed as the means \pm SD and compared using the Student's t-test and ANOVA. A P-value of $<0.05$ was considered statistically significant.

\section{Results}

Effect of OCT on SKOV3/DDP cell proliferation. The SKOV3/ DDP cells were round, fully shaped, cytoplasm-rich and grew vigorously under normal conditions. Following OCT treatment, the the number of adherent normal cells gradually decreased, inter-cell spacing became larger, parts of the cells shrank, cytoplasmic particle deposition was observed, the refractive index became weak and parts of the cells displayed morphological features of apoptosis (shrinkage, foaming and 

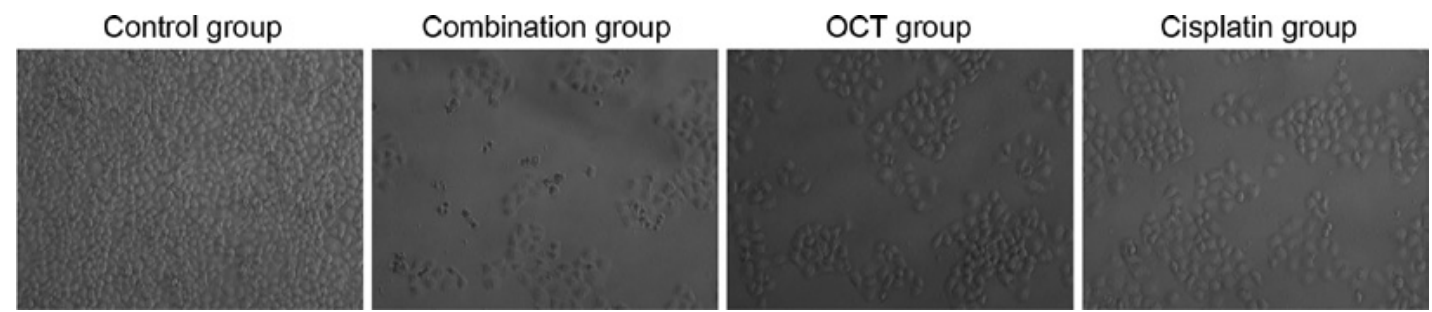

Figure 1. Effect of cisplatin, OCT and the two-drug combination on SKOV3/DDP cell morphology.

Table II. Inhibition rate of OCT on SKOV3/DDP cell proliferation at the indicated concentration and time.

\begin{tabular}{lccccc}
\hline Groups & OCT concentration $(\mu \mathrm{g} / \mathrm{ml})$ & I $(24 \mathrm{~h})$ & II $(48 \mathrm{~h})$ & III $(72 \mathrm{~h})$ & IV $(96 \mathrm{~h})$ \\
\hline 1 & 0 & 0 & 0 & 0 & 0 \\
2 & $1.25^{\mathrm{a}}$ & $5.35 \pm 0.33$ & $5.94 \pm 0.20$ & $7.02 \pm 0.72^{\mathrm{f}, \mathrm{g}}$ & $12.95 \pm 0.23^{\mathrm{f}, \mathrm{g}, \mathrm{h}}$ \\
3 & $2.50^{\mathrm{a}, \mathrm{b}}$ & $10.15 \pm 0.40$ & $12.23 \pm 0.93^{\mathrm{f}}$ & $13.58 \pm 1.21^{\mathrm{f}}$ & $16.91 \pm 0.86^{\mathrm{f}, \mathrm{g}, \mathrm{h}}$ \\
4 & $5.00^{\mathrm{a}, \mathrm{b}, \mathrm{c}}$ & $13.42 \pm 0.28$ & $14.91 \pm 0.15^{\mathrm{f}}$ & $17.18 \pm 1.00^{\mathrm{f}, \mathrm{g}}$ & $23.08 \pm 0.67^{\mathrm{f}, \mathrm{g}, \mathrm{h}}$ \\
5 & $10.00^{\mathrm{a}, \mathrm{b}, \mathrm{c}, \mathrm{d}}$ & $20.89 \pm 0.88$ & $26.23 \pm 1.49^{\mathrm{f}}$ & $34.48 \pm 1.99^{\mathrm{f}, \mathrm{g}}$ & $47.73 \pm 1.09^{\mathrm{f}, \mathrm{g}, \mathrm{h}}$ \\
6 & $20.00^{\mathrm{a}, \mathrm{b}, \mathrm{c}, \mathrm{d}, \mathrm{e}}$ & $32.94 \pm 0.64$ & $44.36 \pm 2.08^{\mathrm{f}}$ & $48.20 \pm 2.17^{\mathrm{f}, \mathrm{g}}$ & $53.22 \pm 1.31^{\mathrm{f}, \mathrm{g}, \mathrm{h}}$ \\
\hline
\end{tabular}

${ }^{\text {a }} \mathrm{P}<0.05$ vs. group $1 ;{ }^{\mathrm{b}} \mathrm{P}<0.05$ vs. 2 ; ${ }^{\mathrm{c}} \mathrm{P}<0.05$ vs. 3 ; ${ }^{\mathrm{d}} \mathrm{P}<0.05$ vs. 4 ; ${ }^{\mathrm{e}} \mathrm{P}<0.05$ vs. $5 .{ }^{\mathrm{f}} \mathrm{P}<0.05$ vs.time $\mathrm{I} ;{ }^{9} \mathrm{P}<0.05$ vs. II; ${ }^{\text {h}} \mathrm{P}<0.05$ vs. III.
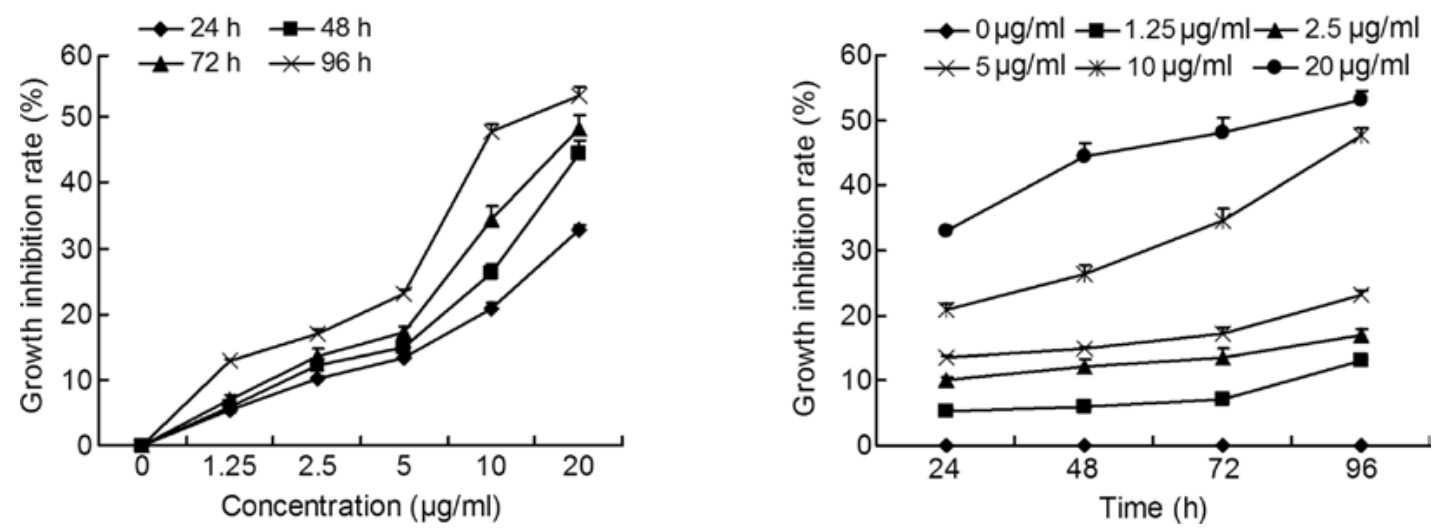

Figure 2. Effect of OCT on the SKOV3/DDP cell growth inhibition rate at the indicated concentration and time.

formation of apoptotic bodies). However, the cells were transparent, with a good refractive index and cell spreading, had smooth and complete edges and were the same size and shape as the control group.

As the treatment time progressed, cell growth became slow and there were increased numbers of falling floating cells, necrotic and debris cells. Fig. 1 shows the cell morphology following $48 \mathrm{~h}$ of OCT treatment. OCT exhibited an inhibitory effect on SKOV3/DDP cell proliferation beginning at the concentration of $1.25 \mu \mathrm{g} / \mathrm{ml}$. An increase in the treatment concentration enhanced the inhibitory effect. When the concentration of OCT was $>5 \mu \mathrm{g} / \mathrm{ml}$, the inhibition rate on SKOV3/DDP cell proliferation was markedly increased. Significant differences were achieved between the control group and each of the OCT treatment groups. Significant differences were also achieved among the OCT treatment groups at different concentrations $(\mathrm{P}<0.05)$. Notably, OCT $(5$, 10 and $20 \mu \mathrm{g} / \mathrm{ml})$ inhibited proliferation in a time-dependent manner ( $\mathrm{P}<0.05$; Table II, Fig. 2).
Effects of OCT and cisplatin combination on SKOV3/DDP growth inhibition rate and cisplatin $I C_{50}$ value. Following treatment at the indicated concentrations of OCT and cisplatin, the optical density (OD) was measured to calculate the cell growth inhibition rate. Compared to the control group, OCT decreased the $\mathrm{IC}_{50}$ value of cisplatin in a dose-dependent manner. A low dose of OCT $(1.25 \mu \mathrm{g} / \mathrm{ml})$ had no significant effect on the $\mathrm{IC}_{50}$ of cisplatin ( $\left.\mathrm{P}>0.05\right)$. However, a higher dose of OCT $(2.5-20 \mu \mathrm{g} / \mathrm{ml})$ significantly inhibited the $\mathrm{IC}_{50}$ value $(\mathrm{P}<0.05$; Table III, Fig. 3). The combination drug indices (CDI) were calculated and are listed in Table IV:

$\mathrm{CDI}=$ Survival rate $_{(\mathrm{A} \text { drug }+\mathrm{B} \text { drug })} /$ (survival rate $_{(\mathrm{A} \text { drug })} \mathrm{x}$ survival rate $\left._{(\mathrm{B} \mathrm{drug})}\right)$.

A CDI $<1$ indicates synergistic effects of the cellular toxicity of drugs $\mathrm{A}$ and $\mathrm{B}$ in the combined treatment. It was shown that CDI was $<1$ when the concentration of OCT and cisplatin was $>5$ and $2 \mu \mathrm{g} / \mathrm{ml}$, respectively, demonstrating the synergistic effect of OCT and cisplatin. 
Table III. Effect of the OCT and cisplatin combination treatment on the SKOV3/DDP cell growth inhibition rate and $\mathrm{IC}_{50}$ value of cisplatin.

\begin{tabular}{|c|c|c|c|c|c|c|}
\hline \multirow[t]{2}{*}{ Cisplatin $(\mu \mathrm{g} / \mathrm{ml})$} & \multicolumn{6}{|c|}{ OCT $(\mu \mathrm{g} / \mathrm{ml})$} \\
\hline & 0 & 1.25 & 2.5 & 5 & 10 & 20 \\
\hline 1 & $8.09 \pm 0.33$ & $8.6096 \pm 0.59$ & $17.3773 \pm 0.49$ & $20.975 \pm 0.74$ & $31.097 \pm 0.30$ & $50.4904 \pm 0.66$ \\
\hline 2 & $10.77 \pm 0.23$ & $12.3908 \pm 0.35$ & $20.6732 \pm 0.41$ & $27.7701 \pm 0.96$ & $39.3251 \pm 0.40$ & $58.553 \pm 0.74$ \\
\hline 4 & $24.15 \pm 0.61$ & $23.3519 \pm 0.81$ & $29.2118 \pm 0.79$ & $41.1858 \pm 0.81$ & $50.7865 \pm 0.84$ & $64.4795 \pm 0.77$ \\
\hline 8 & $36.91 \pm 0.22$ & $31.95 \pm 0.61$ & $42.07 \pm 0.64$ & $50.58 \pm 0.67$ & $59.7633 \pm 0.57$ & $68.3467 \pm 0.82$ \\
\hline $\mathrm{IC}_{50}$ & $14.33 \pm 0.16^{\mathrm{a}}$ & $13.85 \pm 0.88$ & $10.59 \pm 0.25$ & $6.42 \pm 0.14$ & $3.76 \pm 0.08$ & $0.85 \pm 0.09$ \\
\hline
\end{tabular}

${ }^{\mathrm{a}} \mathrm{P}>0.05$.

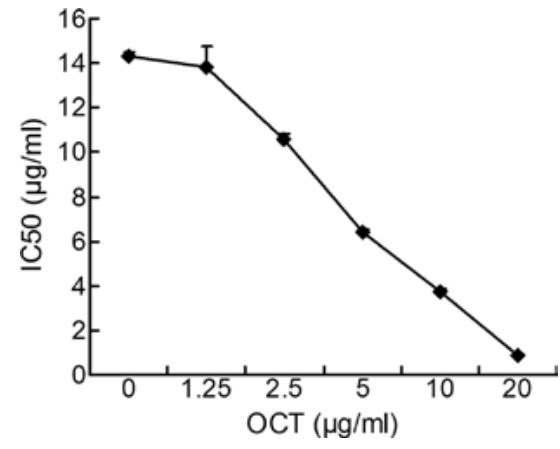

Figure 3. Effect curve of different concentrations of OCT on cisplatin $\mathrm{IC}_{50}$.

Effectofcisplatin,OCTand theircombinationonSKOV3/DDP cell apoptosis. In contrast to the control group, apoptosis was induced in both the OCT $(10 \mu \mathrm{g} / \mathrm{ml})$ and cisplatin $(2 \mu \mathrm{g} / \mathrm{ml})$ groups $(\mathrm{P}<0.05)$. This effect was much more powerful in the combination treatment group than in the individual treatment groups $(\mathrm{P}<0.05)$. However, no significant difference was noted between the OCT and cisplatin treatment groups (P>0.05; Fig. 4).

EGFR, MDR1, MRP2 and GST- $\pi$ mRNA expression in SKOV3/DDP cells. Fig. 5 shows that, compared to the control group, OCT at different concentrations $(2.5,5$ and $10 \mu \mathrm{g} / \mathrm{ml})$ decreased EGFR and MRP2 mRNA expression in a dosedependent manner following $48 \mathrm{~h}$ of treatment $(\mathrm{P}<0.05)$. The basal mRNA level of MDR1 was low, but both the GST- $\pi$ and SSTR2 mRNA expression was detectable. OCT markedly increased the GST- $\pi$ mRNA expression $(\mathrm{P}<0.05)$, but not that of MDR1 and SSTR2 (P>0.05).

\section{Discussion}

Platinum-based combination chemotherapy is the most widely used method in the treatment of ovarian cancer. However, due to resistance, it often fails to cure patients. Therefore, the reversal of platinum resistance in ovarian cancer and increased sensitivity to platinum-based chemotherapy drugs are crucial issues.

SST is a cyclic polypeptide hormone, which is located in most human organs and tissues. It functions in the inhibition of hormone secretion, regulation of neural transmission and
Table IV. Combination drug indices of OCT and cisplatin.

\begin{tabular}{lcccc}
\hline Cisplatin $(\mu \mathrm{g} / \mathrm{ml})$ & \multicolumn{4}{c}{ OCT $(\mu \mathrm{g} / \mathrm{ml})$} \\
\cline { 2 - 5 } & 2.5 & 5 & 10 & 20 \\
\hline 1 & 1.02 & 1.01 & 1.01 & 0.97 \\
2 & 1.01 & 0.95 & 0.92 & 0.83 \\
8 & 1.06 & 0.91 & 0.88 & 0.84 \\
\hline
\end{tabular}

cell proliferation $(2,3)$. Natural SST is limited in clinical applications because of its low selectivity and short half-life. Moreover, reincreases in hormone levels occur after the termination of drug treatment. However, SSTA is widely used in the clinic and has been shown to have more powerful effects and a longer half-life. OCT is the most widely used SSTA in clinical applications. Recently, the inhibitory effects of SST and SSTA on cancer cells have attracted the attention of researchers (9). A body of studies have reported that SST and SSTA inhibit the growth of several non-neuroendocrine tumors $(3,10-12)$, and it is known that the functions of SST and SSTA are mediated by the SSTR (13). SSTR2, followed by SSTR1, 3 and 4, are widely expressed in tumor tissues. Yet, the expression and functions of SSTR in ovarian cancer remain unclear.

Previous studies have shown that the SSTR is expressed in ovarian cancer $(6,14)$. Halmos et al $(6)$ used RT-PCR to investigate the mRNA expression of all subtypes of SSTR in 17 cases of primary ovarian tumor tissue. They found that $76 \%$ of the cases had advanced primary malignant ovarian tumors with high SSTR expression. Among the cases with malignant ovarian tumors and high expression of SSTR, $65 \%$ of the patients exhibited high expression of SSTR1 and SSTR2, followed by SSTR3 and then SSTR5. These data suggest that SST and SSTA may be potential targets for ovarian cancer therapy. In this study, SKOV3/DDP cells expressed SSTR2, and OCT effectively inhibited the proliferation of cisplatin-resistant ovarian cancer SKOV3/DDP cells in a dose-dependent manner and suppressed apoptosis. Our data confirmed that SST and SSTA, as endogenous hormones, regulate ovarian cancer proliferation. One or several SSTRs, particularly SSTR2, were found to be expressed on the surface 

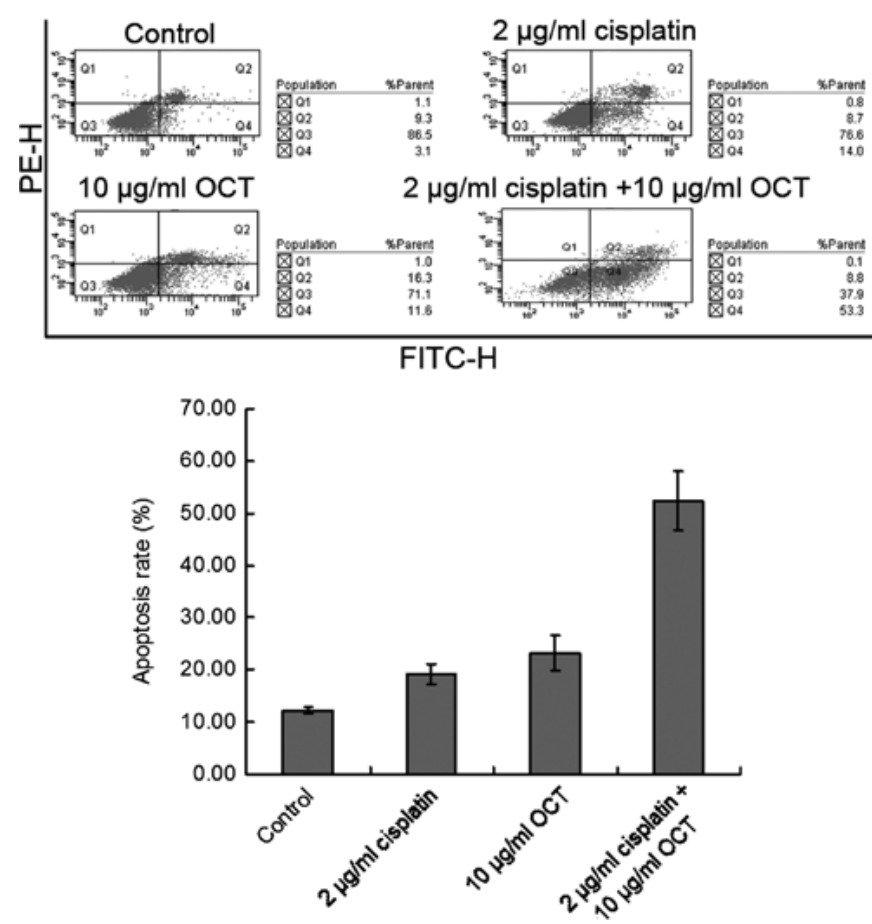

Figure 4. Effects of cisplatin, OCT and the drug combination on SKOV3/ DDP cell apoptosis.

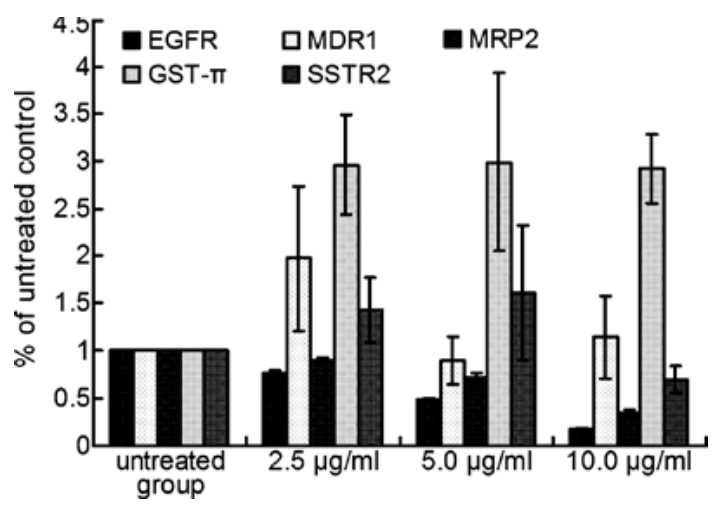

Figure 5. Effect of OCT on SSTR2, EGFR, MDR1, MRP2 and GST- $\pi$ mRNA expression in SKOV3/DDP cells.

of most tumor cells, which was inhibited by SST and SSTA $(15,16)$. OCT was found to exhibit the highest binding affinity to SSTR2 and subsequently inhibits the activity of tyrosine phosphatase and the proliferation of SSTR2-expressing cells (17). However, OCT did not alter the SSTR2 expression level, which is not consistent with a previous study by Hua et al. Their study showed that the short-term application of OCT induces SSTR2 desensitization and internalization, which partially inhibits the effect of OCT in liver cancer cells (18). These contrary results may be due to the different cell characteristics, expression of the receptor and their subtypes and a high OCT treatment concentration. Furthermore, mRNA is not reliable as an index to reflect the status of the receptor, and we should therefore focus on the cell membrane localized receptor protein (19). The SSTR expression in ovarian cancer cells and the mechanism of the inhibitory effects of OCT on proliferation merit further study.
It has been shown that the synergistic effects of SSTA with chemotherapy drugs increase their clinical efficacy. These effects were found to enhance the sensitivity of several gastrointestinal cancers to chemotherapeutic drugs (20). Cisplatin plays an important role in the treatment of ovarian cancer. Yet, it has rarely been reported that OCT increases clinical efficacy when patients with SSTR-expressing ovarian cancer undergo chemotherapy. In this study, OCT reduced the $\mathrm{IC}_{50}$ value of cisplatin in SKOV3/DDP cells in a dose-dependent manner, inhibited SKOV3/DDP cell proliferation, increased the chemotherapeutic sensitivity of cisplatin and reversed chemotherapy resistance. These data suggest that OCT reverses SKOV3/DDP cell resistance and increases the efficacy of chemotherapy in ovarian cancer. However, the detailed mechanism is not yet clear. We investigated the expression of the MDR1, MRP2, GST- $\pi$ and EGFR resistance-related genes using real-time PCR assays, and compared the parameters prior to and after OCT treatment.

In the present study, MRP2 and EGFR were expressed on the SKOV3/DDP cell surface. OCT treatment increased cisplatin sensitivity, induced synergistic cellular cytotoxic effects with cisplatin and decreased MRP2 and EGFR expression. These data demonstrate that OCT reverses ovarian cancer resistance which may be related to the down-regulation of MRP2 and EGFR expression. MRP is an ATP-dependent membrane transport protein, and participates with MRP2 in cisplatin transport in combination with glutathione. Animal experiments and clinical studies have shown that MRP2 is associated with cisplatin resistance in ovarian cancer $(21,22)$. Based on these observations, we hypothesized that MRP2 down-regulation increases the intracellular cisplatin concentration to efficiently reverse drug resistance. The mechanism involved in the OCT reduction of EGFR expression in ovarian cancer is not clear. However, studies have shown that EGFR overexpression in ovarian cancer cells indicates an increase in drug resistance. Suppressing EGFR expression in ovarian cancer cells increases cisplatin sensitivity (23-25). Following OCT binding with SSTR, the activation of the tyrosine phosphatase and the reversal of EGF-induced EGFR tyrosine kinase phosphorylation results in the reduction of EGFR, the termination of EGF signal transduction at the cell membrane and, eventually, the inhibition of cell proliferation (23). EGFR is the producer of the oncogene ErbB1. It has the ability to connect the G-protein, cytokine receptors, integrins and other signals, and affects related gene expression (26). Therefore, OCT may also, indirectly through EGFR, regulate the reversal of cisplatin resistance in vitro. These detailed mechanisms merit further investigation.

MDR1 was found to decrease the intracellular cisplatin concentration by encoding cell surface transporter protein $\mathrm{p}$-gp, resulting in reduced or loss of drug function and induced resistance in ovarian cancer cells $(27,28)$. This study demonstrated no MDR1 expression alteration in SKOV3/DDP cells following the combination treatment of OCT and cispaltin, suggesting that MDR1 is not involved in OCT-mediated inhibition of cell proliferation and reversal of cisplatin resistance. GST- $\pi$ expression in ovarian cancer is not only related to the primary cancer, but also to acquired drug resistance (29). In the present study, GST- $\pi$ gene expression was increased, but not decreased after treatment. Vanhoefer 
et al (30) reported that drugs had an outward flow caused by the non-specific binding of GST- $\pi$ to the p-gp-induced drug pump at the early-stage of resistance. Both the GST- $\pi$ and p-gp are involved in the modulation of early stage drug resistance development (30). The synergistic effects of GST- $\pi$ and $p$-gp may explain why GST- $\pi$ and $\mathrm{p}$-gp are not down-regulated upon the OCT-induced reversal of cisplatin resistance. Of note, cisplatin resistance may be aggravated during the process of OCT-induced reversal for the non-down-regulated changes of GST- $\pi$ and p-gp. The signficance of these changes require further in vivo studies for verification.

Animal studies are on-going. However, in vitro results have confirmed the sensitization effect of OCT in ovarian cancer cisplatin resistance. This finding provides a new target for ovarian cancer therapy. Large-scale, randomized, double-blind and controlled studies need to be carried out in order to ascertain the optimal OCT dose and timing of clinical treatment.

\section{Acknowledgements}

This study was supported by the Technology Research project of Nanjing City (no. 200901089).

\section{References}

1. Harries M and Kaye SB: Recent advances in the treatment of epithelial ovarian cancer. Expert Opin Investig Drugs 10: 1715-1724, 2001

2. Yano T, Radulovic S, Osuga Y, Kugu K, Yoshikawa H, Taketani Y and Schally AV: Inhibition of human epithelial ovarian cancer cell growth in vitro by somatostatin analog RC-160. Oncology 59 (Suppl 1): 45-49, 2000.

3. Pyronnet S, Bousquet C, Najib S, Azar R, Laklai H and Susini C: Antitumor effects of somatostatin. Mol Cell Endocrinol 286 230-237, 2008

4. Robbins RJ: Somatostatin and cancer. Metabolism 45: 98-100, 1996.

5. Pawlikowski M: [The incidence of somatostatin receptors in human neoplasms in the light of ex vivo-in vitro studies] Endokrynol Pol 57: 238-243, 2006 (In Polish).

6. Halmos G, Sun B, Schally AV, Hebert F and Nagy A: Human ovarian cancers express somatostatin receptors. J Clin Endocrinol Metab 85: 3509-3512, 2000.

7. Hall GH, Turnbull LW, Richmond I, Helboe L and Atkin SL: Localisation of somatostatin and somatostatin receptors in benign and malignant ovarian tumours. Br J Cancer 87: 86-90, 2002.

8. Qin YY, Li JY,Li SG, Yue JN and Quan ZW: [Mechanism research in somatostatin reverting the chemosensitivity of GBC-SD cell line]. Zhonghua Wai Ke Za Zhi 46: 381-383, 2008 (In Chinese).

9. Guillermet-Guibert J, Lahlou H, Cordelier P, Bousquet C, Pyronnet S and Susini C: Physiology of somatostatin receptors. J Endocrinol Invest 28: 5-9, 2005.

10. Samonakis DN, Moschandreas J, Arnaoutis T, Skordilis P, Leontidis C, Vafiades I and Kouroumalis E: Treatment of hepatocellular carcinoma with long acting somatostatin analogues. Oncol Rep 9: 903-907, 2002.

11. Vernejoul F, Faure P, Benali N, et al: Antitumor effect of in vivo somatostatin receptor subtype 2 gene transfer in primary and metastatic pancreatic cancer models. Cancer Res 62: 6124-6131, 2002.
12. Zapata PD, Ropero RM, Valencia AM, et al: Autocrine regulation of human prostate carcinoma cell proliferation by somatostatin through the modulation of the $\mathrm{SH} 2$ domain containing protein tyrosine phosphatase (SHP)-1. J Clin Endocrinol Metab 87: 915-926, 2002.

13. Behrens BC, Hamilton TC, Masuda H, et al: Characterization of a cis-diamminedichloroplatinum(II)-resistant human ovarian cancer cell line and its use in evaluation of platinum analogues. Cancer Res 47: 414-418, 1987.

14. Jones RH, Reubi JC, Millan D and Vasey P: Octreotide: an active agent in epithelial ovarian carcinoma? Lancet Oncol 5: 251-253, 2004.

15. Barnett P: Somatostatin and somatostatin receptor physiology. Endocrine 20: 255-264, 2003.

16. LiM,LiW,Kim HJ, YaoQ, Chen CandFisherWE: Characterization of somatostatin receptor expression in human pancreatic cancer using real-time RT-PCR. J Surg Res 119: 130-137, 2004.

17. Murphy E, Prommer E and Mihalyo M: Octreotide. J Pain Symptom Manage 40: 142-148, 2010.

18. Gabriel M, Andergassen U, Putzer D, et al: Individualized peptide-related-radionuclide-therapy concept using different radiolabelled somatostatin analogs in advanced cancer patients. Q J Nucl Med Mol Imaging 54: 92-99, 2010.

19. Hua YP, Yin XY, Peng BG, Li SQ, Lai JM, Liang HZ and Liang LJ: Mechanisms and influence of octreotide-induced regulation of somatostatin receptor 2 on hepatocellular carcinoma. Chemotherapy 55: 312-320, 2009.

20. Diaconu CC, Szathmari M, Keri G and Venetianer A: Apoptosis is induced in both drug-sensitive and multidrug-resistant hepatoma cells by somatostatin analogue TT-232. Br J Cancer 80: 1197-1203, 1999.

21. Schrenk D, Baus PR, Ermel N, Klein C, Vorderstemann B and Kauffmann HM: Up-regulation of transporters of the MRP family by drugs and toxins. Toxicol Lett 120: 51-57, 2001.

22. Surowiak P, Materna V, Kaplenko I, et al: ABCC2 (MRP2, cMOAT) can be localized in the nuclear membrane of ovarian carcinomas and correlates with resistance to cisplatin and clinical outcome. Clin Cancer Res 12: 7149-7158, 2006.

23. Mishima M, Yano T, Jimbo H, et al: Inhibition of human endometrial cancer cell growth in vitro and in vivo by somatostatin analog RC-160. Am J Obstet Gynecol 181: 583-590, 1999.

24. Park SJ, Armstrong S, Kim CH, Yu M, Robertson K, Kelley MR and Lee SH: Lack of EGF receptor contributes to drug sensitivity of human germline cells. Br J Cancer 92: 334-341, 2005.

25. Chan JK, Pham H, You XJ, et al: Suppression of ovarian cancer cell tumorigenicity and evasion of cisplatin resistance using a truncated epidermal growth factor receptor in a rat model. Cancer Res 65: 3243-3248, 2005.

26. Kang ES, Oh MA, Lee SA, et al: EGFR phosphorylationdependent formation of cell-cell contacts by Ras/Erks cascade inhibition. Biochim Biophys Acta 1773: 833-843, 2007.

27. Lukyanova NY: Characteristics of homocysteine-induced multidrug resistance of human MCF-7 breast cancer cells and human A2780 ovarian cancer cells. Exp Oncol 32: 10-14, 2010.

28. Schondorf T, Kurbacher CM, Gohring UJ, et al: Induction of MDR1-gene expression by antineoplastic agents in ovarian cancer cell lines. Anticancer Res 22: 2199-2203, 2002.

29. Ghalia AA, Rabboh NA, el Shalakani A, Seada L and Khalifa A: Estimation of glutathione S-transferase and its $\mathrm{Pi}$ isoenzyme in tumor tissues and sera of patients with ovarian cancer. Anticancer Res 20: 1229-1235, 2000.

30. Vanhoefer U, Yin MB, Harstrick A, Seeber S and Rustum YM: Carbamoylation of glutathione reductase by N,N-bis(2-chloroethyl)$\mathrm{N}$-nitrosourea associated with inhibition of multidrug resistance protein (MRP) function. Biochem Pharmacol 53: 801-809, 1997. 